\title{
Hepatitis (C) Virus, Hepatitis (B) Virus and Human Immunodeficiency (HIV) Virus Coinfection and Their Impact Outcome on the Liver Said Abdelbaky Gad ${ }^{1}$, Ahmed I. Elagrody ${ }^{2}$ \\ Department of Internal Medicine, Faculty of Medicine, Zagazig University \\ Corresponding author: Said Abd Elbaky Gad Shams El Deen, Mobile: (+20)01227517689, Email: saidabdelbaky12345@gmail.com
}

\begin{abstract}
Background: Hepatitis C virus (HCV), hepatitis B virus (HBV) and human immunodeficiency virus (HIV) are the commonest chronic viral infections worldwide, they share most common routes of infections, they are hepatotropic viruses and their combined infections had bad outcome on the liver.

Objective: To evaluate the risk of coinfection of the liver by both HCV, HBV and HIV on the liver outcome.

Patients and Methods: This is a retrospective study of 241 patients attending different fever hospitals coinfected by $\mathrm{HCV}$ and or HBV with HIV but not HCV or HBV without HIV infections.

Result: There was significant difference between male 59.8\% and female $40.2 \%$, age of patients, also there was significant difference as regard liver enzymes, cirrhosis, splenomegaly, international normalization ratio in triplet coinfections.
\end{abstract}

Conclusion: There is high risk on liver outcome in the presence of coinfection between HCV or HBV and HIV.

\section{INTRODUCTION}

Human immunodeficiency virus (HIV) is a lentivirus which target the immune system resulting in depression of cell mediated immunity with resulting serious opportunistic infection and rare malignances ${ }^{(\mathbf{1})}$.

Worldwide hepatitis (B) virus, hepatitis (C) virus and human immunodeficiency virus (HIV) are the commonest chronic viral infections. They have common routes of transmissions as they are blood born infectious diseases (blood and blood products), needle transmission, and sexual activity (2). HBV is characterized by special route of transmission which is the vertical one (from mother to baby) which is rare in HCV. Coinfection between the three hepatotropic viruses are of great risk as the viruses may impact the natural history of the other one, HIV accelerates the natural course of both HBV and HCV with consequent destructive effect on the liver and progression to cirrhosis and hepatocellular carcinoma (HCC). Worldwide among HIV infected patients about 2-4 millions have chronic HBV coinfection and 4-5 million coinfected with $\mathrm{HCV}^{(3)}$.

In Egypt about 2-3 million are chronic carriers for $\mathrm{HBV}$ and 6-8 million are $\mathrm{HCV}$ positive patients so we decided to study the effect of coinfection between HIV and HCV and HBV on the liver outcome in some Egyptian fever hospitals in a retrospective study ${ }^{(4)}$.

HBV and HCV coinfection with HIV in very important as triplet infection increase the risk of hepatological complications ${ }^{(\mathbf{5})}$.

As infection with the triplet viruses may hasten the scarring of the liver with consequent cirrhosis and hepatocellular carcinoma (HCC) life expectancy with these viruses are decreased ${ }^{(}{ }^{(}$. Infection by the three viruses is different according to geographic regions and behavior of infected persons ${ }^{(7)}$. It is unclear how many people have

HIV in the country so we decided to study in crosssection of retrospective study the true triplet coinfection and its effect on the liver ${ }^{(\mathbf{6}, \mathbf{8})}$.

Aim of the work was to evaluate the risk of coinfection of the liver by both HCV, HBV and HIV and the liver outcome.

\section{PATIENTS AND METHODS}

This study is a cross sectional study between Mayo 2018 and June 2019. It included 241 patients with no sex predilection aged between 20-75 years old attending Alexandria, Al Abasia and Al Ahrar fever hospitals. This study depended on file records of patients attending these hospitals to follow up and treatment. Objectively this study measures the prevalence of coinfection between HIV, HCV and HBV but not HCV or HBV alone without HIV infection and its impact out come on the liver.

\section{Ethical approval:}

An approval of the study was obtained from Zagazig University academic and ethical committee. Every patient signed an informed written consent for acceptance of the operation.

\section{Inclusion criteria:}

All patients included in the study had HIV infection with work up to investigate other serological markers of $\mathrm{HCV}$ and HBV but not $\mathrm{HCV}$ or HBV alone.

\section{Exclusion criteria:}

Any patient have any liver disease weather acute or chronic and patients with HCV or HBV without HIV.

All patients included in the study were subjected to filling data records of age, sex, onset of disease, 
course duration, complications clinical assessment, family history, sexual history and drug history.

\section{Laboratory investigations:}

- Routine laboratory investigations CBC, ESR, CRP.

- Kidney function tests.

- Complete liver function tests.

- Bleeding profile; PT, PTT, and INR.

- Tumour marker Alfa foetoprotein.

- Serological makers.

- HBC infection by HBV surface antigen (HBsag) positivity but negative HBVC Ab (core antibody).

- HCV infection by HCRAB (HCV antibody) positivity and confirmed by $\mathrm{HCV}$ polymerase reaction (PCR).

- HIV infection by ELTSA test (Enzyme linked immunosorbent assay).

\section{RESULT}

Table (1): Age and gender of the studied group

\begin{tabular}{|c|c|c|c|}
\hline \multicolumn{2}{|c|}{ Mean \pm SD } & \multicolumn{2}{c|}{ Age } \\
\hline \multicolumn{2}{|c|}{ Median } & \multicolumn{2}{c|}{$38.19 \pm 8.5$} \\
\hline \multirow{3}{*}{ Sex } & & N & $\%$ \\
\cline { 2 - 4 } & Male & 97 & 40.2 \\
\cline { 2 - 4 } & Female & 144 & 59.8 \\
\cline { 2 - 4 } & Total & 241 & 100.0 \\
\hline
\end{tabular}

Table (2): Some characters of the studied group

\begin{tabular}{|c|c|c|c|}
\hline & & $\mathbf{N}$ & $\%$ \\
\hline \multirow[t]{2}{*}{ Addiction } & No & 199 & 82.6 \\
\hline & Yes & 42 & 17.4 \\
\hline \multirow[t]{2}{*}{ Smoking } & No & 170 & 70.5 \\
\hline & Yes & 71 & 29.5 \\
\hline \multirow{2}{*}{ Splenomegaly } & No & 192 & 79.7 \\
\hline & Yes & 49 & 20.3 \\
\hline \multirow[t]{3}{*}{ Cirrhosis } & No & 217 & 90.0 \\
\hline & Yes & 24 & 10.0 \\
\hline & Total & 241 & 100.0 \\
\hline
\end{tabular}

Table 3 is showing levels of of AST, ALT, Urea, Cr, PT and INR in the studied groups.

Table (3): Lab measurements of the studied group

\begin{tabular}{|l|c|c|c|c|c|c|}
\hline & AST & ALT & Urea & Cr & PT & INR \\
\hline Mean \pm SD & $39.56 \pm 13.5$ & $44.18 \pm 14.6$ & $29.24 \pm 9.54$ & $1.04 \pm 0.21$ & $\begin{array}{c}12.43 \pm 2.0 \\
1\end{array}$ & $1.11 \pm 0.18$ \\
\hline Median & 30.0 & 32.0 & 27.0 & 1.0 & 12.4 & 1.1 \\
\hline
\end{tabular}

Table (4): Frequency of opportunistic infection in the studied group

\begin{tabular}{|c|c|c|c|}
\hline \multirow{2}{*}{ Pneumonia } & & $\mathbf{N}$ & \% \\
\cline { 2 - 4 } & $-\mathrm{VE}$ & 161 & 66.8 \\
\hline \multirow{2}{*}{ UTI } & $+\mathrm{VE}$ & 80 & 33.2 \\
\cline { 2 - 4 } & $-\mathrm{VE}$ & 232 & 96.3 \\
\hline \multirow{2}{*}{ Meningitis } & $+\mathrm{VE}$ & 9 & 3.7 \\
\cline { 2 - 4 } & $-\mathrm{VE}$ & 147 & 61.0 \\
\cline { 2 - 4 } & $+\mathrm{VE}$ & 94 & 39.0 \\
\cline { 2 - 4 } & Total & 241 & 100.0 \\
\hline
\end{tabular}


Table (5): Prevalence of the viruses' coinfection in the studied group

\begin{tabular}{|c|c|c|c|}
\hline \multirow{3}{*}{ Groups } & & $\mathbf{N}$ & $\mathbf{\%}$ \\
\hline \multirow{4}{*}{} & HIV only & 169 & 70.1 \\
\cline { 2 - 4 } & HIV+HBV & 20 & 8.3 \\
\cline { 2 - 4 } & HIV+HCV & 39 & 16.2 \\
\cline { 2 - 4 } & HIV+HBV+HCV & 13 & 5.4 \\
\cline { 2 - 4 } & Total & 241 & 100.0 \\
\hline
\end{tabular}

Table (6): Comparison among the studied patients according to viruses' coinfection.

Data are presented as mean \pm SD or as number and percentage

\begin{tabular}{|c|c|c|c|c|c|c|c|c|}
\hline & $\begin{array}{c}\text { HIV only } \\
\text { N=169 }\end{array}$ & $\begin{array}{c}\mathrm{HIV}+\mathrm{HBV} \\
\mathrm{N}=20\end{array}$ & $\begin{array}{c}\mathrm{HIV}+\mathrm{HCV} \\
\mathrm{N}=39\end{array}$ & $\begin{array}{c}\mathrm{HIV}+\mathrm{HBV}+\mathrm{H} \\
\mathrm{CV} \mathrm{N}=13\end{array}$ & $\mathbf{F}$ & $\mathbf{P}$ \\
\hline \multicolumn{3}{|c|}{ Age (years) } & $34.21 \pm 6.24 \#$ & $44.75 \pm 2.55$ & $46.56 \pm 3.88$ & $54.56 \pm 5.28 *$ & 101.624 & $0.001 * *$ \\
\hline \multicolumn{3}{|c|}{ AST (U/L) } & $29.61 \pm 5.53$ & $95.6 \pm 16.33^{*}$ & $34.25 \pm 8.5$ & $89.23 \pm 13.82 *$ & 527.509 & $0.001 * *$ \\
\hline \multicolumn{3}{|c|}{ ALT (U/L) } & $31.86 \pm 5.76$ & $102.0 \pm 20.4^{*}$ & $36.35 \pm 7.08$ & $93.15 \pm 13.5^{*}$ & 504.709 & $0.001 * *$ \\
\hline \multicolumn{3}{|c|}{ Urea $(\mathrm{mg} / \mathrm{dL})$} & $28.36 \pm 6.01$ & $26.1 \pm 1.02$ & $26.56 \pm 5.49$ & $28.61 \pm 9.5$ & 2.731 & 0.187 \\
\hline \multicolumn{3}{|c|}{$\mathrm{Cr}(\mathrm{mg} / \mathrm{dL})$} & $1.018 \pm 0.15$ & $1.0 \pm 0.211$ & $1.01 \pm 0.14$ & $1.08 \pm 0.41$ & 1.102 & 0.324 \\
\hline \multicolumn{3}{|c|}{ PT } & $11.84 \pm 1.53^{*}$ & $13.18 \pm 1.83$ & $13.09 \pm 1.22$ & $13.95 \pm 2.93$ & 14.189 & $0.001 * *$ \\
\hline \multicolumn{3}{|c|}{ INR } & $1.08 \pm 0.103^{*}$ & $1.14 \pm 0.05$ & $1.11 \pm 0.16$ & $1.12 \pm 0.24$ & 31.028 & $0.001 * *$ \\
\hline \multirow[t]{4}{*}{ Sex } & \multirow[t]{2}{*}{ Male } & $\mathrm{N}$ & 55 & 9 & 24 & 9 & \multirow{5}{*}{16.2} & \multirow{5}{*}{$0.001 * *$} \\
\hline & & $\%$ & $32.5 \%$ & $45.0 \%$ & $61.5 \%$ & $69.2 \%$ & & \\
\hline & \multirow[t]{2}{*}{ Female } & $\mathrm{N}$ & 114 & 11 & 15 & 4 & & \\
\hline & & $\%$ & $67.5 \%$ & $55.0 \%$ & $38.5 \%$ & $30.8 \%$ & & \\
\hline \multirow[t]{4}{*}{ Addiction } & \multirow[t]{2}{*}{ No } & $\mathrm{N}$ & 149 & 20 & 26 & 4 & & \\
\hline & & $\%$ & $88.2 \%$ & $100.0 \%$ & $66.7 \%$ & $30.8 \%$ & \multirow{3}{*}{38.99} & \multirow{3}{*}{$0.001 * *$} \\
\hline & \multirow[t]{2}{*}{ Yes } & $\mathrm{N}$ & 20 & 0 & 13 & 9 & & \\
\hline & & $\%$ & $11.8 \%$ & $0.0 \%$ & $33.3 \%$ & $69.2 \%$ & & \\
\hline \multirow[t]{4}{*}{ Smoking } & \multirow[t]{2}{*}{ No } & $\mathrm{N}$ & 140 & 11 & 15 & 4 & \multirow{4}{*}{43.83} & \multirow{5}{*}{$0.001 * *$} \\
\hline & & $\%$ & $82.8 \%$ & $55.0 \%$ & $38.5 \%$ & $30.8 \%$ & & \\
\hline & \multirow[t]{2}{*}{ Yes } & $\mathrm{N}$ & 29 & 9 & 24 & 9 & & \\
\hline & & $\%$ & $17.2 \%$ & $45.0 \%$ & $61.5 \%$ & $69.2 \%$ & & \\
\hline Spleno- & No & $\mathrm{N}$ & 160 & 0 & 28 & 4 & & \\
\hline megaly & & $\%$ & $94.7 \%$ & $0.0 \%$ & $71.8 \%$ & $30.8 \%$ & \multirow{3}{*}{122.5} & \\
\hline & Yes & $\mathrm{N}$ & 9 & 20 & 11 & 9 & & $0.001 * *$ \\
\hline & & $\%$ & $5.3 \%$ & $100.0 \%$ & $28.2 \%$ & $69.2 \%$ & & \\
\hline Cirrhosis & No & $\mathrm{N}$ & 169 & 20 & 24 & 4 & & \\
\hline & & $\%$ & $100.0 \%$ & $100.0 \%$ & $61.5 \%$ & $30.8 \%$ & & \\
\hline & Yes & $\mathrm{N}$ & 0 & 0 & 15 & 9 & 107.17 & $0.001 * *$ \\
\hline & & $\%$ & $0.0 \%$ & $0.0 \%$ & $38.5 \%$ & $69.2 \%$ & & \\
\hline Pneumonia & No & $\mathrm{N}$ & 121 & 11 & 25 & 4 & & \\
\hline & & $\%$ & $71.6 \%$ & $55.0 \%$ & $64.1 \%$ & $30.8 \%$ & & \\
\hline & Yes & $\mathrm{N}$ & 48 & 9 & 14 & 9 & 10.78 & $0.013^{*}$ \\
\hline & & $\%$ & $28.4 \%$ & $45.0 \%$ & $35.9 \%$ & $69.2 \%$ & & \\
\hline UTI & No & $\mathrm{N}$ & 160 & 20 & 39 & 13 & & \\
\hline & & $\%$ & $94.7 \%$ & $100.0 \%$ & $100.0 \%$ & $100.0 \%$ & & \\
\hline & Yes & $\mathrm{N}$ & 9 & 0 & 0 & 0 & 3.98 & 0.26 \\
\hline & & $\%$ & $5.3 \%$ & $0.0 \%$ & $0.0 \%$ & $0.0 \%$ & & \\
\hline Meningitis & No & $\mathrm{N}$ & 106 & 11 & 26 & 4 & & \\
\hline & & $\%$ & $62.7 \%$ & $55.0 \%$ & $66.7 \%$ & $30.8 \%$ & & \\
\hline & Yes & $\mathrm{N}$ & 63 & 9 & 13 & 9 & 6.03 & 0.11 \\
\hline & & $\%$ & $37.3 \%$ & $45.0 \%$ & $33.3 \%$ & $69.2 \%$ & & \\
\hline & & $\mathrm{N}$ & 169 & 20 & 39 & 13 & & \\
\hline & & $\%$ & $100.0 \%$ & $100.0 \%$ & $100.0 \%$ & $100.0 \%$ & & \\
\hline
\end{tabular}

Age was significantly younger among $1^{\text {st }}$ group and significantly older among $4^{\text {th }}$ group. AST, ALT were significantly higher among $2^{\text {nd }}$ and $4^{\text {th }}$ groups. As regard PT and INR they were significantly lower among $1^{\text {st }}$ group. Addiction was significantly associated with last group. Splenomegaly was significantly associated with $2^{\text {nd }}$ and $4^{\text {th }}$ group. Cirrhosis was with $3^{\text {rd }}$ and $4^{\text {th }}$ and as regard pneumonia it was significantly associated with $2^{\text {nd }}$ and $4^{\text {th }}$ group. 


\section{DISCUSSION}

HIV, HBV and HCV are still major public health problems. Infections with these viruses rank among ten leading causes of death attributable to infectious diseases ${ }^{(8,9)}$. The variability in the prevalence of $\mathrm{HIV} /$ hepatitis coinfection worldwide is multi factorial, and depends on geographic distributions, infections risk factors and route of exposure ${ }^{(9)}$.

HC/HIV coinfection has been associated with rapid decline in CD4 count, rapid progression of HIV infection and increased morbidity and mortality. HCV and HBV coinfection with HIV accelerates disease progression ${ }^{(\mathbf{1 0})}$. Individuals coinfected with HIV/HBV are more likely to develop chronic hepatitis B with increased risk for acquiring liver related mortality. In Egypt, number of people living with HIV in 2017 was approximately 22000 individuals ${ }^{(\mathbf{1 1}, \mathbf{1 2})}$.

The mean age of patients in our study was $38.19 \pm 8.5$ which is in close association with a study done by Rebbasni et al. ${ }^{(13)}$ (under 40 years) and it is also in agreement with the study done at Bojuwoye $\boldsymbol{e t}$ al. ${ }^{(8)}(33 \pm 9)$. As regard sex distribution; in our study females were $59.8 \%$ and males were $40.2 \%$, which is in agreement with a study done by Azevedo et al. ${ }^{(14)}$ and disagreement with a study done by Konopnicki $\boldsymbol{e t}$ al. ${ }^{(15)}$ with male predominance.

As regard other parameters $17.4 \%$ were addicted, $29.5 \%$ was smokers, $20.3 \%$ had splenomegaly and $10 \%$ has liver cirrhosis. Moreover sexual transmission was $78 \%$, and drug, abuse was $22 \%$ which was in agreement with studies done by Rebbasani et al. ${ }^{(13)}$ and Graham et al. ${ }^{(16)}$ as sexual transmission was the main route of infection. In addition to the above; HIV represented $70.1 \%$ alone, HIV + HBV 8.3\%, HIV + HCV 16.2 and HIV, HBV, HCV (triplet infection) 5.4. Other studies showed anti$\mathrm{HCV}$ positive prevalence in HIV infected patients ranged between 3.3\% in South Africa, $42.3 \%$ in North America, $9.1 \%$ in Libya, $32.4 \%$ as found by Tremeau et al. ${ }^{(1)}$, Cooper et al. ${ }^{(2)}$ and Koziel et al. ${ }^{(17)}$. As regard HB sero prevalence in HIV; in our study it was 8.3\%. Also our study found increased ALT and AST. Addiction was significant with HIV + HCV + HBV (triplet infection), splenomegaly was significantly enlarged in HIBV + HIV and triplet infection groups, cirrhosis was highly significant in HCV + HIV and triplet infection groups, and also pneumonia was significantly high with $\mathrm{HBV}+\mathrm{HIV}$ and triplet infection groups. HIV infection was significantly high in younger age group while in triplet infection group it was significantly high in old age.

Our study found that HIV was highly significant in younger age group (sexually active groups, more prone to drug abuse and overactive in the community, but triplet infection in older age group (decreased immunity). Also our study had revealed that bleeding parameters (PT, INR) were significantly high in double or triple infections. As regard HIV infection alone (liver parenchyma dysfunction) HIV and HBV and triplet infection had significant AST elevations than other groups. Our study had revealed also that patients addicting drugs were significantly more with triplet coinfection.

Our study also showed significant level in prevalence of meningitis in combined and triplet confection.

\section{CONCLUSION}

From the results of our study we concluded that:

- HIV infection occurs more in younger age groups (sexually active group + drug addicts).

- Liver complications as cirrhosis, splenomegaly are more common in combined infection.

- Opportunistic infection is also common in combined infection.

\section{RECOMMENDATION}

Strict follow up, diagnosis of HIV individuals with associated hepatotropic viral infection as HBV and HCV is mandatory to avoid complications and mass screening of peoples at high risk.

\section{REFERENCES}

1. Tremeau- Bravard I, Ogbukagu C, Ticao J et al. (2012): Seroprevalence of hepatitis B and C infection among the HIV-positive population in Abuja, Nigeria. African Health Sciences, 12:312317.

2. Cooper C, Mills E, Wabwire B et al. (2009): Chronic viral hepatitis may diminish the gains of HIV antiretroviral therapy in Sub-Saharan Africa. Int J Infect Dis., 13(3):302-6.

3. Alter M (2006): Epidemiology of viral hepatitis and HIV co-infection. J Hepatol., 44: 6-9.

4. Kim J, Psevdos G, Suh J et al. (2088): Co-infection of hepatitis B and hepatitis $\mathrm{C}$ virus in human immunodeficiency virus infects patients in New York City United States. Worl J Gastroenterol., 14(43) 668993.

5. Beltrami E, Williams I, Shapiro C et al. (2000): Risk and management of blood borne infections in health care workers. Clin Microbiol Rev., 13(3): 385-407.

6. Den Brinker M, Wit F, Wertheim-van P et al. (2000): Hepatitis B and C virus co-infection and the risk for hepatotoxicity of highly active antiretroviral therapy in HIV-1 infection. AIDS., 14(18):28952902.

7. Quinn T, Wawer M, Sewankambo N et al. (2000): Viral Load and heterosexual transmission of human immunodeficiency virus type 1 . N Engl J Med., 342 (13):921-9.

8. Bojuwoye B (1997): The burden of viral hepatitis in Africa. West Afr J Med., 16(4):198-203.

9. Dore G, Soriano V, Rockstroh J et al. (2010): Frequent hepatitis B virus rebound among HIV-hepatitis B viruscoinfected patients following antiretroviral therapy interruption. AIDS., 24(6):857-865.

10. Bosh K, Coyle J, Hansen V et al. (2018): HIV and viral hepatitis coinfection analysis using surveillance data from 15 US states and two cities. Epidemiol Infect., 146(7):920-930. 
11.Egyptian Ministry of Health and Population (2010): Family health institutional, the United States Agency for International Development. National HIV/AIDS Clinical Care. https://www.fhi360.org/sites/default/files.pdf

12.El-Zanaty F, Way A (2006): Egypt demographic and health service 2005. Cairo: Ministry of Health and Population. com/pubs/pdf/FR176/FR176.pdf

13. Rebbasni K, Ouladlahsen A, Bensghir A et al. (2013): Co-infections with hepatitis $\mathrm{B}$ and $\mathrm{C}$ viruses in human immunodeficiency irus-infected patients in Morocco. ClinMicrobiol Infect., 19(10):454-7.

14. Azevedo T, Zwahlen M, Rauch A et al. (2016): Hepatitis $\mathrm{C}$ in HIV-infected individuals: a systematic review and meta-analysis of estimated prevalence in Africa. J Int AIDS Soc., 19(1):20711-14.

15. Konopnicki D, Mocroft A, de Wit S et al. (2005): Hepatitis B and HIV: prevalence, AIDS progression, response to highly active antiretroviral therapy and increased mortality in the EuroSIDA cohort. AIDS., 19(6):593-601.

16. Graham C, Baden L, Yu E et al. (2001): Influence of human immunodeficiency virus infection on the course of hepatitis $C$ virus infection: a meta-analysis. Clin Infect Dis., 33(4):562-569.

17. Koziel M, Peters M (2007): Viral Hepatitis in HIV Infection. N Engl J Med., 356(14):1445-1454. 